
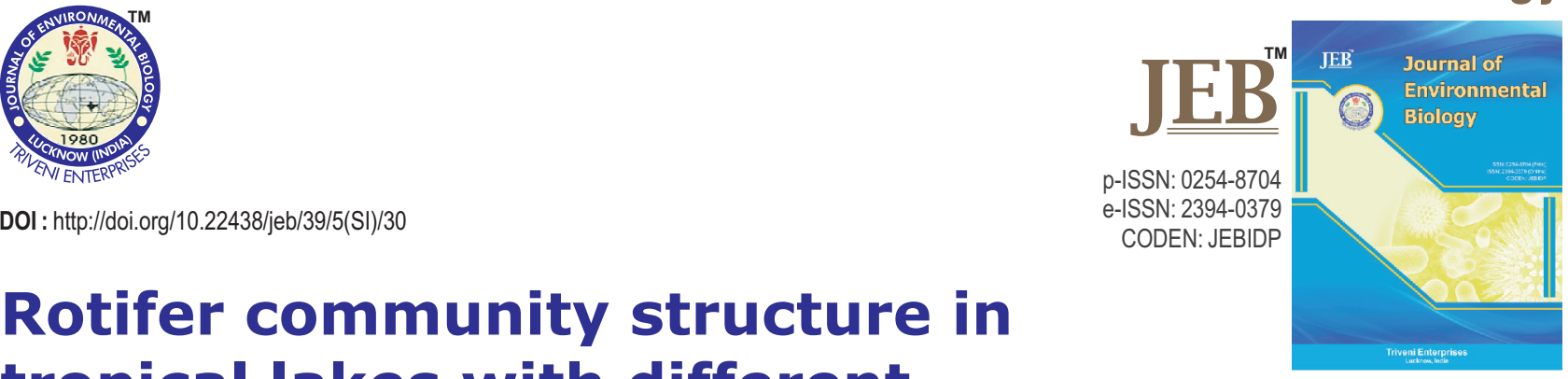

\title{
Rotifer community structure in tropical lakes with different environmental characteristics related to ecosystem health
}

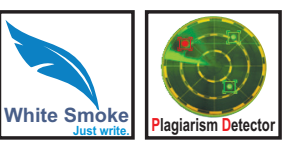

\section{Authors Info}

W.A.D. Umi', F.M. Yusoff ${ }^{12 *}$, A.Z. Aris ${ }^{3}$ and Z. Sharip ${ }^{4}$

'Laboratory of Marine Biotechnology, Institute of Bioscience, Universiti Putra Malaysia, 43400 Serdang, Selangor, Malaysia

2Department of Aquaculture, Faculty of Agriculture, Universiti Putra Malaysia, 43400 Serdang, Selangor, Malaysia

${ }^{3}$ Department of Environmental Sciences, Faculty of Environmental Studies, Universiti Putra Malaysia, 43400 Serdang, Selangor, Malaysia

${ }^{4}$ Lake Research Unit, Water Quality and Environment Research Centre, National Hydraulic Research Institute of Malaysia, 43300 Seri Kembangan, Selangor, Malaysia

*Corresponding Author Email : fatimahyus@gmail.com

Key words

Community structure

Eutrophic

Mesotrophic

Rotifers

Tropical lakes

Publication Info

Paper received: 08.05.2017

Revised received: 07.07.2017

Re-revised received : 15.10 .2017

Accepted : 28.12.2017

\begin{abstract}
Aim: This study was conducted to evaluate the rotifer composition and abundance in lakes with different environmental characteristics in an attempt to identify the relationship between the rotifer community structure and environmental parameters.

Methodology: Bimonthly samplings were carried out in Sembrong, Putrajaya and Subang lakes from April 2015 to February 2016. Duplicate rotifer samples were collected with a $60 \mu \mathrm{m}$ mesh net using vertical hauls from about $30 \mathrm{~cm}$ from bottom to the surface, and preserved with $10 \%$ buffered formalin to produce $5 \%$ final solution for identification and enumeration. Physico-chemical parameters were measured in situ using YSI multi-parameter, and nutrient analyses were accomplished upon arrival in the laboratory of Marine Biotechnology, Universiti Putra Malaysia.
\end{abstract}

Results: A recently created meso-eutrophic Putrajaya lake had the highest number of rotifer species (11 families and 28 species), followed by the hypereutrophic Sembrong lake (10 families and 24 species). In the acidic-mesotrophic lake, only 17 species of rotifers from nine families were found. In this acidic water-body, Ptygura libera was the most dominant species contributing to $76.1 \%$ of the total rotifer abundance. In Putrajaya lake, Keratella cochlearis contributed to $38.0 \%$ of rotifer populations followed by $P$. libera with $33.0 \%$. Brachionus forficula and Brachionus calyciflorus were dominant in Sembrong lake which made up of $41.2 \%$ of total rotifer species. Putrajaya lake had highest density of rotifers with a total mean density of $239.4 \pm 30.3$ ind. $\Gamma^{-1}$ compared in Sembrong lake (158.7 \pm 16.6 ind. $\left.I^{-1}\right)$ and Subang lake $\left(58.9 \pm 18.5\right.$ ind. $\left.I^{-1}\right)$. The canonical correspondence analysis (CCA) scores indicated that the abundance of $B$. calyciflorus and $B$. forficula was related to the eutrophic condition associated with the high total phosphorus and chlorophyll a. Ptygura libera seemed to be associated in less nutrient rich waters, and seemed to be tolerant to acidic waters.

Interpretation: This study illustrated that the dominance of rotifer species was related to the lake health status. The abundance of Brachionus, Keratella and Trichocerca were related to the eutrophic condition associated with turbidity, total dissolved solid (TDS), chlorophyll a and nutrient concentrations. Ptygura libera seemed to be associated with less nutrient rich water tolerant to acidic waters (pH4-5).

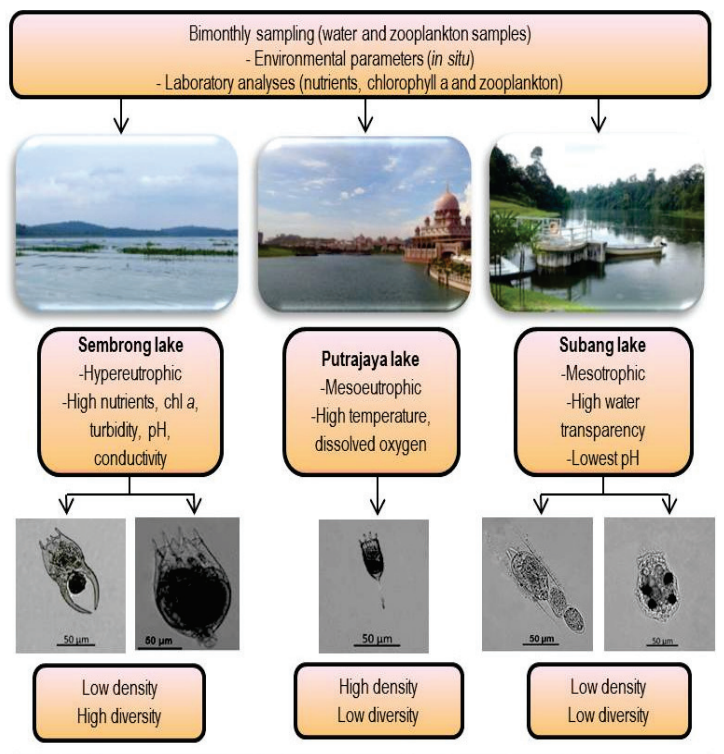

The roffer species composition, density abundance and diversity were related to the environmental conditions of the lake. 


\section{Introduction}

Rotifera is one of the most important freshwater zooplankton groups, in addition to Cladocera and Copepoda. Species composition and abundance of rotifers can be influenced by a number of physical, chemical and biological factors such as temperature, dissolved oxygen, turbidity, $\mathrm{pH}$, nutrient availability, quantity and quality of food, predation and competition in their habitats (Ismail and Zaidin, 2015; Panwar and Malik, 2016; Wang et al., 2016; Sharip and Yusoff, 2017). Rotifer's major food items, such as algae and bacteria which are generally abundant in nutrient-rich environments (Yoshida et al., 2003), also determine their community characteristics. Linking the microbes to the higher levels, rotifers play a vital role in the energy flow and nutrient cycling in aquatic ecosystems, especially when the abundance of large zooplankton such as crustaceans is low (Sanders et al., 1989). Rotifers can act as predators, capable of regulating the populations of phytoplankton, protozoans and bacteria, and serve as food source for fish communities (Arndt, 1993; Offem et al., 2011). They are responsible for the carbon transfer between the microbial food web consisting of bacteria, heterotrophic and mixotrophic flagellates and ciliates, and the classical food chain which include algae, crustacean zooplankton and fish (Alcaraz and Calbet, 2007). For that reason, any perturbation that would change the rotifer community structure would disrupt the aquatic food chain. In addition, rotifers have short life cycles and rapid reproduction rate, mainly through parthenogenesis, which enables them to respond rapidly to environmental changes (Ferdous and Muktadir, 2009). Therefore, rotifer community structure which varies from lake to lake can be used to indicate the real-time environmental health status.

Aquatic ecosystem health is highly correlated with the nutrient contents, pollutant concentrations, water quality status and biotic community structure. Elevated nutrient inputs into the water bodies lead to eutrophication resulting in harmful algal blooms and deterioration of lake water quality, which would in turn affect the zooplankton composition and abundance (Bhat et al., 2015). Rotifer species composition and abundance are suggested to be strongly associated with the ecosystem health status, and individual species may reflect the level of eutrophication (Rogozin, 2000). Eutrophication can cause changes in the species composition and increased abundance of tolerant rotifer species (Špoljar et al., 2011). Increasing rotifer abundance in eutrophic conditions could probably due to enhanced bacterial production due to high decomposition rate of accumulated dead phytoplankton biomass (Karabin, 1985). Some rotifers and small cladoceran species might be competing for the same resources but at the same time, the big cladocerans could prey on rotifers (Brandl, 2005). Rotifers are abundant when small cladocerans $(<1.2 \mathrm{~mm})$ such as Ceriodaphnia and Bosmina are present, but typically rare when large cladocerans $(>1.2 \mathrm{~mm})$ such Daphnia coexist in the same place (Maclsaac and Gilbert, 1989). However, removal of cladocerans by planktivorous fish, which are usually abundant in eutrophic condition, could also be one of the reasons for the rotifer high rate of survival in eutrophic lakes (Gilbert and Stemberger, 1985). The health status of the lake ecosystem is important in determining the composition of rotifer and species abundance. Therefore, this study aimed to evaluate the rotifer species composition and abundance in three lakes with different trophic status and water quality characteristics in order to identify the relationship between the biological components and environmental factors.

\section{Materials and Methods}

Study sites : This study was carried out at three lakes in Malaysia which were Subang, Putrajaya and Sembrong lakes (Fig. 1). Subang lake was located at the Western part of Peninsular Malaysia in a forested area surrounded by newly-developed residential areas. Subang lake was built in early 1950s. It was a small low-land reservoir with a surface area of 66.4 ha and a capacity of 3.5 million $\mathrm{m}^{3}$. The mean depth of the lake was $9.1 \mathrm{~m}$ with the catchment area of $10.2 \mathrm{~km}^{2}$.

Putrajaya lake is located at the Federal Government Administrative Center of Malaysia. This lake was created in 1997 when dams were laid across the Chuau and Bisa rivers. The water surface area of the lake was approximately $400 \mathrm{ha}$, bordered with 200 ha constructed wetlands in the upstream, and stored a total volume of 24 million $\mathrm{m}^{3}$. The depth of the lake ranged from $3-13 \mathrm{~m}$ with a mean of $6.6 \mathrm{~m}$. Its catchment area $\left(50.9 \mathrm{~km}^{2}\right)$ was a part of the bigger Langat river basin within the state of Selangor (Asma' etal., 2014).

Sembrong lake was located at the Southern part of Malaysia in the district of Ayer Hitam, Johor that was constructed in 1981 and completed in 1984. This lake area was about $8.5 \mathrm{~km}^{2}$ with the catchment area of $130 \mathrm{~km}^{2}$, and water capacity of 18 million $\mathrm{m}^{3}$. The major tributaries flowing into this lake were from Sembrong and Marpo rivers. The main purpose of this lake was originally for the flood control, but later it was also used for water supply. It is a shallow lake with a mean depth of $5.1 \mathrm{~m}$ and a maximum depth of $7.2 \mathrm{~m}$. Sembrong lake was eutrophic due to agriculture and animal husbandry activities in the surrounding areas of the lake. For this study, three stations were established in each lake.

Samples collection and analytical method : Bimonthly samplings were carried out from April 2015 to February 2016. At each sampling station, environmental parameters including temperature, dissolved oxygen (DO), conductivity, total dissolved solid (TDS), turbidity and $\mathrm{pH}$ were recorded in situ at $1 \mathrm{~m}$ depth intervals using YSI multi-parameter. Water transparency and depth were measured using a Secchi disc and a depth meter, respectively. Van Dorn water sampler was used to collect water 


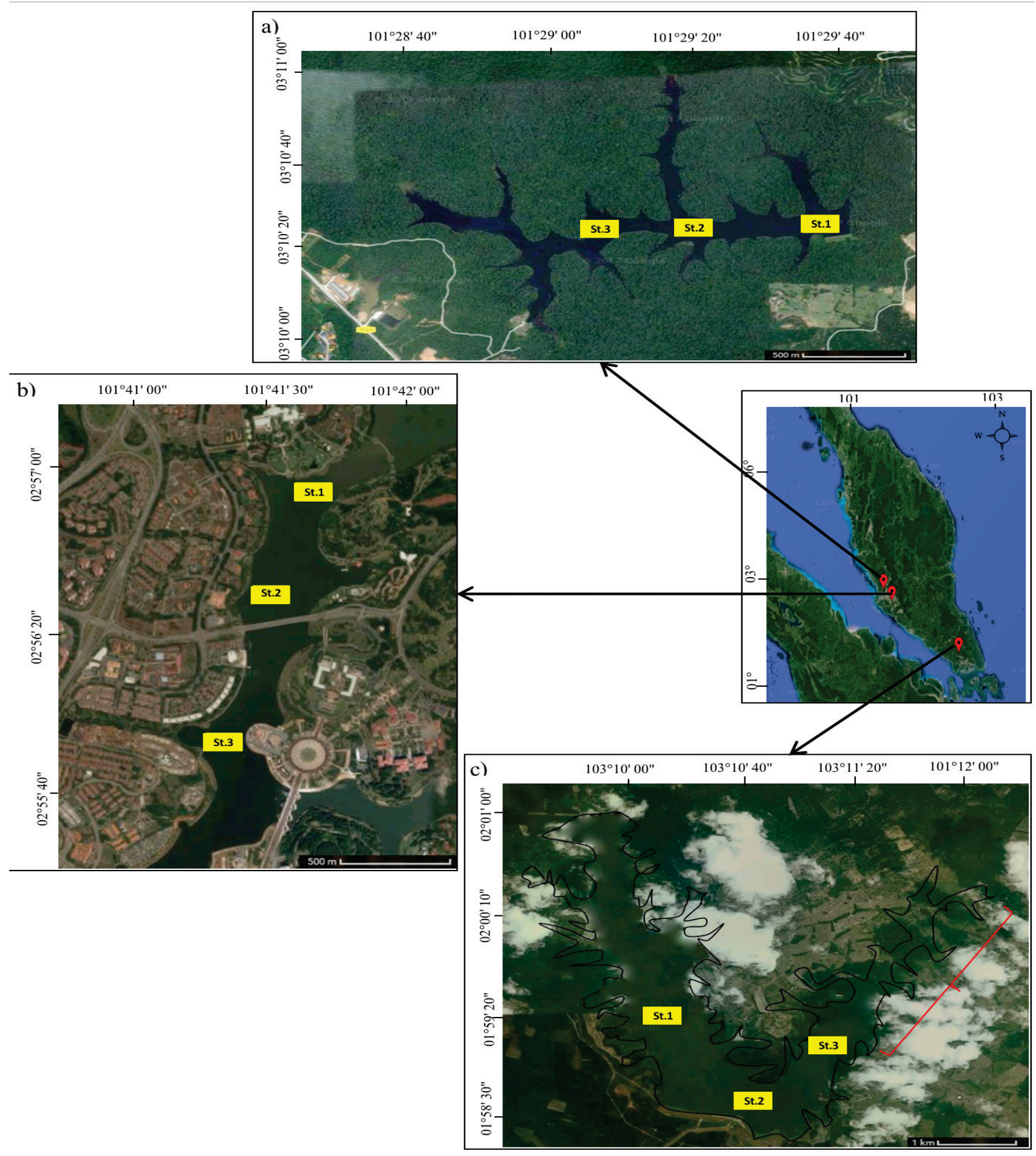

Fig.1 : Map showing sampling locations in (a) Subang, (b) Putrajaya and (c)Sembrong lakes. Note the macrophyte infected section of Sembrong lake on the north-eastern part

samples from three different strata to represent surface, middle and bottom layers of each lake for chlorophyll a determination and nutrient analyses. Samples were transferred into acid-washed polyethylene bottles and kept in ice box during the transportation back to the laboratory. Unfiltered water samples were used for total nitrogen (TN) and total phosphorus (TP) analyses, while filtered water samples through $0.45 \mu \mathrm{m}$ membrane filter were used for total ammonium nitrogen (TAN), soluble reactive phosphorus (SRP) and nitrate and nitrite $\left(\mathrm{NO}_{3}-\mathrm{N}+\mathrm{NO}_{2}-\mathrm{N}\right)$ measurements. For chlorophyll a determination, acidification was 
performed to avoid the effect of pheophytin (Lorenzen, 1967). Total nitrogen and $\mathrm{NO}_{3}-\mathrm{N}+\mathrm{NO}_{2}-\mathrm{N}$ concentrations were determined following the method of Kitamura et al. (1982). Total phosphorus was determined following the method of Jeffries et al. (1979) and Parsons et al. (1984). Soluble reactive phosphorus and TAN were analyzed according to Parsons et al. (1984). Both nutrients and chlorophyll $a$ analyses involved spectrophotometric measurements using a double beam UV-1601 UV visible spectrophotometer (Shimadzu, Japan).

Concurrent with the water sampling, duplicate zooplankton samples were collected vertically at each station with a $60-\mu \mathrm{m}$ mesh net using vertical hauls from about $30 \mathrm{~cm}$ from the bottom to the surface. Samples were transferred into $50 \mathrm{ml}$ of screw cap bottle and preserved using $5 \%$ buffered formalin (final concentration) for zooplankton identification and enumeration in the laboratory. A sample of $1-5 \mathrm{ml}$ (depending on the rotifer density) was placed in Sedgewick-Rafter counting chamber and left to settle for half an hour prior to the transfer to the microscope stage. Random non-overlapping fields were examined until at least 150 individuals of the dominant species were counted and reported as number of individuals $\mathrm{I}^{-1}$ (Lee and McAlice, 1979). Identification of zooplankton was conducted to species level based on descriptions, taxonomic key and illustration by Pontin (1978), Shiel (1995), Segers (2008), Sa-Ardrit et al. (2013) and Phan et al. (2015).

Data analyses : All environmental variables were assessed for normality by the Shapiro-Wilk test prior to statistical analyses. Since most of the data was non-normally distributed, significant differences among environmental variables were determined using Kruskal-Wallis multiple comparison test (differences were considered significant at $p<0.05$ ). Non-parametric Spearman's rank order correlation analyses were conducted on the environmental parameters and rotifer community to determine if there was any significant relationship amongst them. All the statistical analysis was performed using SPSS v. 22 (IBM SPSS Statistical, Chicago, USA). Rotifer abundance data were log $(x+$ 1) transformed to balance the contribution to overall abundances and to reduce the weighing of abundant species and increase that of rarer species (Clarke and Warwick, 2001). Rotifer assemblages were examined for their taxonomic diversity and evenness using Shannon- Wiener diversity index $\left(\mathrm{H}^{\prime}\right)$ and Pielou's evenness index (J'). Bray-Curtis similarity was used to construct a similarity matrix which made-up the basis for a 2-D ordination plot using non-metric multidimensional scaling (NMDS). These analyses were accomplished using PRIMER software package version 6.1.9. XLSTAT software package was used for canonical correspondence analysis (CCA) to show simultaneous representation of sampling lakes, environmental parameters and rotifer assemblages. CCA-derived variation partitioning technique was used to quantify the variation explained by spatial (lake) and environmental subsets of explanatory variables, at the same time to ascertain relationships between the species data and the explanatory variables (Ter Braak and Verdonschot, 1995).

\section{Results and Discussion}

Species composition, abundance and diversity : A total of 32 rotifers species were recorded throughout the sampling period in all lakes studied (Table 1). The highest number of rotifer species was recorded in Putrajaya lake with 28 species from 11 families. While in Sembrong lake, 24 species from 10 families of rotifers were found. Rotifer species identified in the lakes studied were consistent with those found in freshwater localities in Malaysia (Meor Hussain et al., 2002; Shah et al., 2012; Ismail and Adnan, 2016). Based on nutrient concentrations, chlorophyll a and water transparency, Putrajaya and Sembrong lakes were categorized as meso-eutrophic and hypereutrophic lakes, respectively. Sembrong lake showed significantly lower $(p<0.05)$ water transparency and significantly higher $(p<0.05)$ total dissolved solid, turbidity, TP, TN and chlorophyll a that reflected the eutrophic conditions of this lake compared to the other lakes (Fig. 2). The highly eutrophic condition in Sembrong lake was mainly due to agricultural activities around the lake which increased accumulation of nutrients via surface runoff, and consequently boosted the phytoplankton growth (Mohd Asharuddin et al., 2016). In this study, Brachionidae was the major rotifer family with 14 species including Brachionus and Keratella, as the most common ones in Putrajaya and Sembrong lakes (Table 1). Sladecek (1983) and Claps et al. (2011) also reported that higher rotifer species richnes in eutrophic lake was mainly contributed by Brachionidae family. Therefore, the dominance of this genus was expected in both Sembrong and Putrajaya lakes because most Brachionus and Keratella species were reported to be associated with eutrophic conditions (Offem et al., 2011; Mulani et al., 2009).

The relatively high number of rotifer species encountered in Putrajaya and Sembrong lakes could be attributed to the availability of microbial food abundance, associated with the nutrient-enriched condition of these lakes. Generally, high biomass of decomposed phytoplankton in eutrophic waters results in elevated concentrations of detritus and bacteria which form important food sources for rotifers (Gulati, 1990). Therefore, in a more eutrophic lake, the number of rotifer species could be higher. Lin et al. (2013) reported that there were 61 species of rotifers in a eutrophic lake in China. In addition, Paidere et al. (2012) also reported that species richness was higher in more productive lakes compared to oligotrophic or mesotrophic lakes. In contrast, in a turbid lake (66 NTU) in Nigeria, Offem et al. (2011) found only nine rotifer species, probably due to lack of suitable food particles in a highly silty water-body. Thus, the number of rotifer species could be dependent of a number of interacting environmental factors, especially the food availability.

Among lakes, the highest $(p<0.05)$ rotifer density was observed in Putrajaya lake with a total mean density of $239.4 \pm$ 
Table 1: Mean densities (ind. I $^{-1}$ ) and percentages (\%) of rotifer species in Sembrong, Putrajaya and Subang lakes

\begin{tabular}{|c|c|c|c|c|c|c|c|}
\hline Rotifer species & $\begin{array}{l}\text { No. of } \\
\text { species }\end{array}$ & $\begin{array}{l}\text { Sembrong lake } \\
\text { Mean density }\end{array}$ & $\%$ & $\begin{array}{l}\text { Putrajaya lake } \\
\text { Mean density }\end{array}$ & $\%$ & $\begin{array}{l}\text { Subang lake } \\
\text { Mean density }\end{array}$ & $\%$ \\
\hline Asplanchanidae & 1 & & & & & & \\
\hline Asplanchna priodonta & & $0.5 \pm 0.5$ & 0.3 & $0.0 \pm 0.0$ & 0.0 & - & - \\
\hline Brachionidae & 14 & & & & & & \\
\hline Anuraeopsis fissa & & $2.1 \pm 0.9$ & 1.3 & $3.9 \pm 1.6$ & 1.6 & $1.3 \pm 0.1$ & 2.2 \\
\hline Brachionus angularis & & $0.2 \pm 0.2$ & 0.1 & $5.0 \pm 1.2$ & 2.1 & $2.5 \pm 0.0$ & 0.0 \\
\hline Brachionus calyciflorus & & $28.4 \pm 6.5$ & 18.0 & - & - & - & - \\
\hline Brachionus sp. & & $0.6 \pm 0.4$ & 0.4 & $3.0 \pm 1.6$ & 1.3 & - & - \\
\hline Brachionus donneri & & - & - & $0.9 \pm 0.8$ & 0.4 & - & - \\
\hline Brachionus falcatus & & $1.0 \pm 0.4$ & 0.7 & $0.3 \pm 0.2$ & 0.1 & - & - \\
\hline Brachionus forficula & & $36.9 \pm 8.0$ & 23.3 & $5.5 \pm 1.9$ & 2.3 & $0.1 \pm 0.0$ & 0.2 \\
\hline Brachionus sp. & & - & - & $0.1 \pm 0.1$ & 0.0 & - & - \\
\hline Brachionus quadridentatus & & - & - & $1.0 \pm 0.5$ & 0.4 & $0.0 \pm 0.0$ & 0.0 \\
\hline Brachionus sericus & & - & - & - & - & $0.0 \pm 0.0$ & 0.1 \\
\hline Keratella cochlearis & & $0.6 \pm 0.5$ & 0.3 & $91.1 \pm 8.4$ & 38.0 & $0.2 \pm 0.1$ & 0.3 \\
\hline Keratella sp. & & $0.0 \pm 0.0$ & 0.0 & $0.8 \pm 0.5$ & 0.3 & - & - \\
\hline Keratella tropica & & $17.8 \pm 4.8$ & 11.2 & $0.6 \pm 0.5$ & 0.3 & $0.3 \pm 0.2$ & 0.6 \\
\hline Lepadellasp. & & - & - & - & - & $0.0 \pm 0.0$ & 0.0 \\
\hline Filinidae & 4 & & & & & & \\
\hline Filinia camasecla & & $0.1 \pm 0.0$ & 0.1 & $1.2 \pm 0.6$ & 0.5 & - & - \\
\hline Filinia longiseta & & $0.5 \pm 0.5$ & 0.3 & & - & - & - \\
\hline Filinia opoliensis & & $3.8 \pm 0.4$ & 2.4 & $0.0 \pm 0.0$ & 0.0 & $0.0 \pm 0.0$ & 0.0 \\
\hline Filinia terminalis & & $4.9 \pm 1.5$ & 3.1 & $0.0 \pm 0.0$ & 0.0 & - & - \\
\hline Flosculariidae & 1 & & & & & & \\
\hline Ptygura libera & & - & - & $79.2 \pm 28.8$ & 33.0 & $44.8 \pm 10.4$ & 76.1 \\
\hline Gastropodidae & 2 & & & & & & \\
\hline Ascomorpha ecaudis & & - & - & $1.8 \pm 1.8$ & 0.8 & $8.9 \pm 1.5$ & 15.2 \\
\hline Gastropus stylifer & & $0.0 \pm 0.0$ & 0.0 & $0.1 \pm 0.1$ & 0.1 & - & - \\
\hline Hexarthridae & 1 & & & & & & \\
\hline Hexathra mira & & $7.1 \pm 1.0$ & 4.5 & $10.1 \pm 1.5$ & 4.2 & $0.6 \pm 0.2$ & 1.0 \\
\hline Lecanidae & 2 & & & & & & \\
\hline Lecane bulla & & $0.1 \pm 0.1$ & 0.1 & $0.7 \pm 0.6$ & 0.3 & $0.0 \pm 0.0$ & 0.0 \\
\hline Lecane curvicornis & & $0.1 \pm 0.1$ & 0.1 & $0.2 \pm 0.1$ & 0.1 & $0.0 \pm 0.0$ & 0.0 \\
\hline Mytillinidae & 1 & & & & & & \\
\hline Lophocharis sp. & & $0.1 \pm 0$ & 0.0 & $0.6 \pm 0.4$ & 0.3 & - & - \\
\hline Synchaetidae & 1 & & & & & & \\
\hline Polyarthra vulgaris & & $7.9 \pm 3.2$ & 5.0 & $14.9 \pm 7.5$ & 6.2 & $2.1 \pm 0.2$ & 3.6 \\
\hline Testudinellidae & 2 & & & & & & \\
\hline Pompholyx complanata & & $23.1 \pm 9.7$ & 14.6 & $9.6 \pm 6.5$ & 4.0 & $0.0 \pm 0.0$ & 0.0 \\
\hline Pompholyx sulcata & & $0.1 \pm 0.1$ & 0.1 & $0.1 \pm 0.1$ & 0.0 & - & - \\
\hline Trichocercidae & 3 & & & & & & \\
\hline Trichocercasp. & & - & - & $2.8 \pm 1.8$ & 1.2 & - & - \\
\hline Trichocerca elongata & & $0.2 \pm 0.2$ & 0.1 & $0.9 \pm 0.4$ & 0.4 & - & - \\
\hline Trichocerca similis & & $22.6 \pm 6.2$ & 14.2 & $4.8 \pm 0.9$ & 2.0 & $0.1 \pm 0.0$ & 0.1 \\
\hline
\end{tabular}

30.3 ind. $~^{-1}$ and ranged from $154.1 \pm 7.6$ ind..$^{-1}$ in April to $357.1 \pm$ 22.2 ind. ${ }^{-1}$ in October 2015 (Fig. 3). Previous works showed that high density of rotifer was observed in eutrophic lakes (Claps et al. 2011; Perbiche-Neves et al., 2013). Therefore, Sembrong lake was expected to have high rotifer density as it had higher nutrient concentrations which could favor the production of phytoplankton as food resource for rotifer. However, in this study, rotifer mean density $\left(158.7 \pm 16.6\right.$ ind. $\left.{ }^{-1}\right)$ in the eutrophic Sembrong lake was significantly lower $(p<0.05)$ than that in Putrajaya lake $(239.4 \pm$ 30.3 ind. $I^{-1}$ ) (Fig. 3). Lower rotifer density in Sembrong lake might be due to reduced efficiency of energy transfer between phytoplankton and zooplankton (Pederson et al., 1976). Filamentous blue-green algae which formed more than $99 \%$ of the Sembrong lake phytoplankton community could possibly clog filter-feeding apparatus of zooplankton (Sampaio et al., 2002), including rotifers. 
Eutrophic lakes are normally dominated by noxious bluegreen algal species which are mostly inedible food items for zooplankton (Ger et al., 2016). In fact, some blue-green algae produce toxins which could negatively affect zooplankton populations and other planktivores (Ferrão-Filho and KozlowskySuzuki, 2011). In addition to the toxic and inedible blue-green algae, lower rotifer density in Sembrong lake compared to Putrajaya lake could be due to low dissolved oxygen
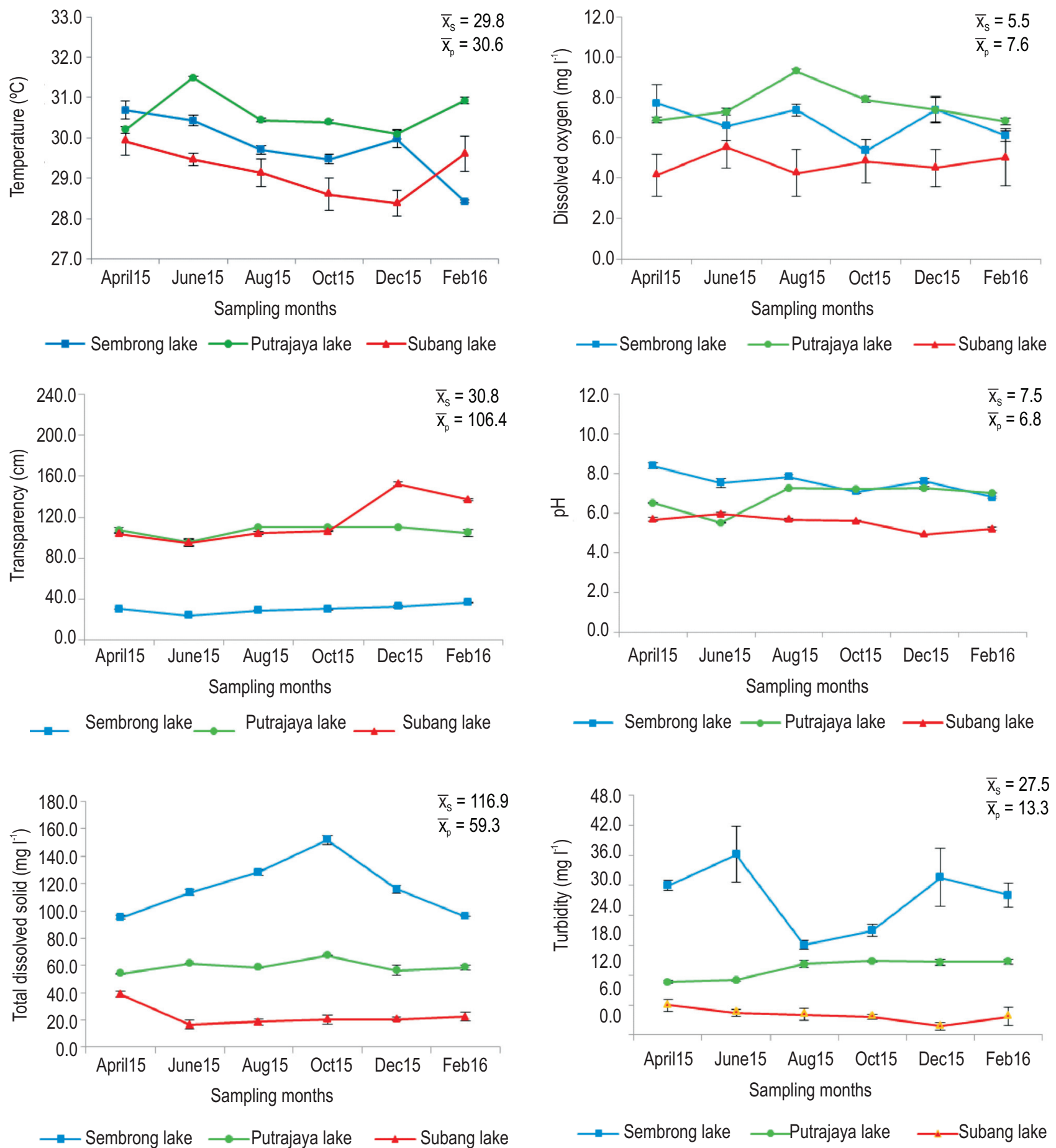

Fig. 2 : Variations of mean environmental parameters measured in different lakes in different sampling months. $S=$ Sembrong lake; $P=$ Putrajaya lake and $\mathrm{Sb}=$ Subang lake 

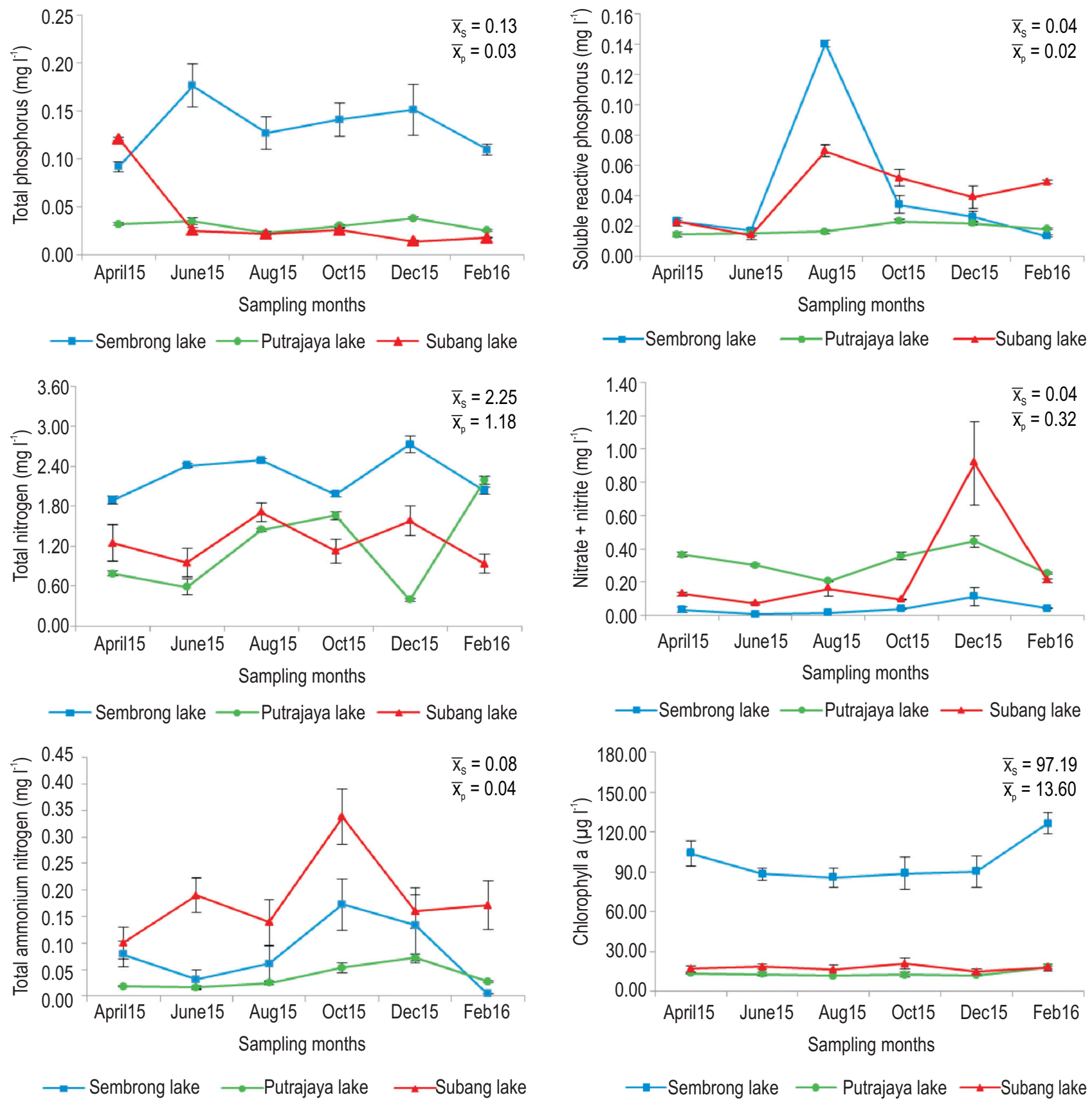

Fig. 2 (cont.) : Variations of mean environmental parameters measured in different lakes in different sampling months. $S=$ Sembrong lake; $P=P$ utrajaya lake and $\mathrm{Sb}=$ Subang lake

concentrations in the former (Fig. 2). Auel and Verheye (2007) reported that hypoxia could cause negative physiological impacts on rotifer species and reduce their populations. In addition, predation by small planktivores such as predatory cyclopoids could also be another reason for lower rotifer density in Sembrong lake. In the same time, crustacean zooplankton community in this lake was dominated by a filter feeder, Ceriodaphnia cornuta. However, the rotifer density $\left(158.7 \pm 16.6\right.$ ind. I $\left.^{-1}\right)$ recorded in eutrophic Sembrong lake was higher compared to that reported by Ismail and Adnan (2016) who found only 70.0 ind . I $^{-1}$ and Meor Hussain et al. (2002) who noted 66.0 ind. $I^{-1}$ in other eutrophic lakes in Malaysia.

The slightly acidic Subang lake exhibited the lowest $(p<0.05)$ rotifer density with the mean density of $58.9 \pm 18.5$ ind..$^{-1}$ amongst the three lakes examined. In this lake, the highest density was observed in June $2015\left(144.9 \pm 26.7\right.$ ind. $\left.I^{-1}\right)$ and the lowest was in February 2016 (26.3 \pm 19.3 ind..$\left.^{-1}\right)$ (Fig. 3). Subang 


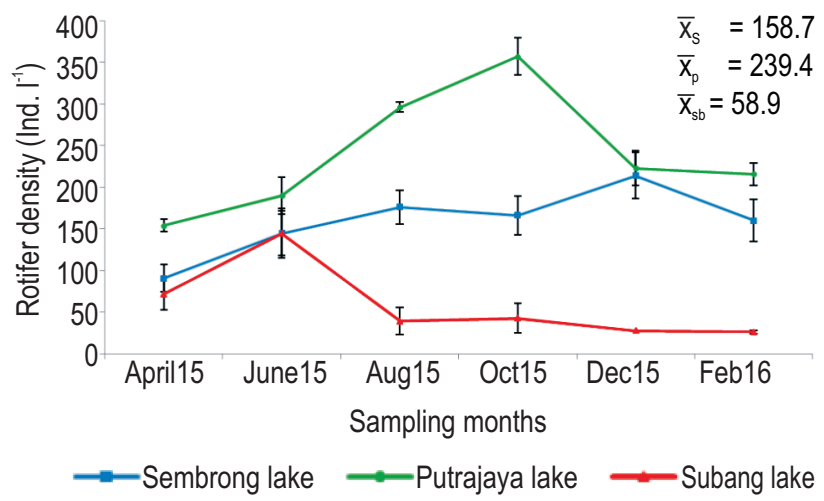

Fig. 3 : Monthly variation of rotifer densities in Sembrong, Putrajaya and Subang lakes. $S=$ Sembrong lake; $P=$ Putrajaya lake; $S b=$ Subang lake

lake showed significantly lower $(p<0.05) \mathrm{pH}$ compared to other lakes. Lower $\mathrm{pH}$ values could be one of the reasons for the lower rotifer density in this. Derry and Arnott (2007) reported that zooplankton is $\mathrm{pH}$-sensitive and disappears due to acidification. Water with low $\mathrm{pH}$ encourages the solubility of heavy metals such as aluminum, lead and copper which are readily released into the water. High concentration of aluminum could limit the growth and reproduction of aquatic organisms (Locke, 1991). In addition, heavy metals ingested by zooplankton could lead to physiological damage (Knops et al., 2001), and could hamper the rotifer growth and reproduction. Besides, low $\mathrm{pH}$ considerably reduces growth of phytoplankton populations which serve as the food for the herbivorous zooplankton (Berge et al., 2010).

In this study, rotifer assemblage of Sembrong lake was dominated by Brachionus forficula (23.3\%), B. calyciflorus (18.0 $\%$ ) and Trichocerca similis (14.2\%) of all the samples (Table 1). Brachionus calyciflorus and $B$. forficula showed high densities in June 2015 (41.8\%) and August 2015 (42.5\%), respectively (Fig. 4a). This finding was supported by Tasevska et al. (2012) who found that Brachionus, especially $B$. calyciflorus was the most abundant species in eutrophic lake. Pal et al. (2015) noted that B. calyciflorus was tolerant to high level of organic pollution. In Sembrong lake, $T$. similis also contributed to a significant percentage of the total rotifer density with high abundance recorded in April 2015 (44.6\%). This finding was similar to Sladecek (1983) who also noted that Brachionus and Trichocerca were abundant in eutrophic lakes in the temperate region. Brachionus species appeared to be well adapted in lakes with high trophic status because they are feeders of bacteria, detritus and particulate organic matter which are highly available in eutrophic environment (Bērzinš and Pejler, 1989; Paidere et al., 2012). Even though high trophic conditions are associated with high abundance of blue-green algae, Brachionus is reported to have high tolerance to cyanobacterial toxins (Karabin et al., 1997) and have ability to utilize colonial blue-green algae as food and exhibit a great tolerance to their blooms (Fulton et al., 1987). Brachionus's tolerance to these adverse factors explains why it is one of the genera which could thrive in high densities in eutrophic Sembrong lake.

In Putrajaya lake, the major species was Keratella cochlearis which contributed to $38.0 \%$ of rotifer populations followed by P. libera with $33.0 \%$ (Table 1). In this lake, occasional dominance peaks were observed, with $K$. cochlearis dominating in April 2015 (65.0\%) and December $2015(59.2 \%)$, while P. libera was dominant in October 2015 (59.0\%) and February 2016 $(61.8 \%)$ (Fig. 4b). These two species contributed most to the total rotifer abundance, especially in June 2015, October 2015 and February 2016 in which their abundance exceeded $90.0 \%$. Frutos et al. (2009) reported similar trend for Keratella sp. in mesotrophic lakes. In addition, $K$. cochlearis was also reported in high proportion in eutrophic lakes ("Spoljar et al., 2011, EjsmontKarabin, 2012). Some rotifer species are regarded as indicators of lake trophic status including most of the taxa from the genera Brachionus, Keratella, Filinia, Pompholyx and Trichocerca (Karabin, 1985). Among them, the dominance of two genera, Brachionus and Keratella has been regularly reported in lake with increasing trophic status (Frutos et al., 2009; Mulani et al., 2009; Hsieh et al., 2011). Therefore, the present study indicated the prevalence of Keratella, Brachionus and Trichocerca species in enriched mesoeutrophic and eutrophic Putrajaya and Sembrong lakes, respectively. This study showed that rotifer's preferences for different habitats are also attributed to food types available.

Subang lake showed a clear domination of $P$. libera contributing to $76.1 \%$ of the total rotifers (Table 1). Ptygura libera was dominant in almost all sampling months, especially in April 2015 forming $93.6 \%$ of the total rotifers (Fig. 4c). The dominance of $P$. libera could be attributed to the fact that this species is a ' $r$ ' strategist which has wide tolerance to variety of environmental variables (Neves et al., 2003). It was observed that the emergence of $A$. ecaudis started in June 2015 and this species completely replaced $P$. libera in February 2016 which exceeded $80.2 \%$ of the total rotifer density.

Even though the number of species was less in Sembrong lake, its rotifer diversity was highest $\left(H^{\prime}=1.9 \pm 0.0, p<\right.$ $0.05)$ compared to other lakes, most probably due to higher evenness $\left(\mathrm{J}^{\prime}=0.7 \pm 0.0\right)$ of rotifer species distribution in the former (Table 2). This observation is consistent with that Frutos et al. (2009) who obtained high diversity $\left(H^{\prime}=1.9\right)$ in a eutrophic lake. Similarly, Demetraki-Paleolog and Sender (2013) also reported higher rotifer diversity $\left(H^{\prime}=1.7\right)$ in eutrophic lake. In addition, high diversity of rotifer species in Sembrong lake could also be related to dense macrophytes coverage as epiphytic algae which were abundant on submerged macrophytes are a preferred food source for rotifers (van Donk and van de Bund, 2002). On the other hand, the lowest diversity in Subang lake $\left(H^{\prime}=0.8 \pm 0.1, p<\right.$ $0.05)$ was probably due to the lower evenness $\left(\mathrm{J}^{\prime}=0.3 \pm 0.0\right)$ value that coincided with the domination of $P$. libera from April 2015 - December 2015. This study demonstrated that the 

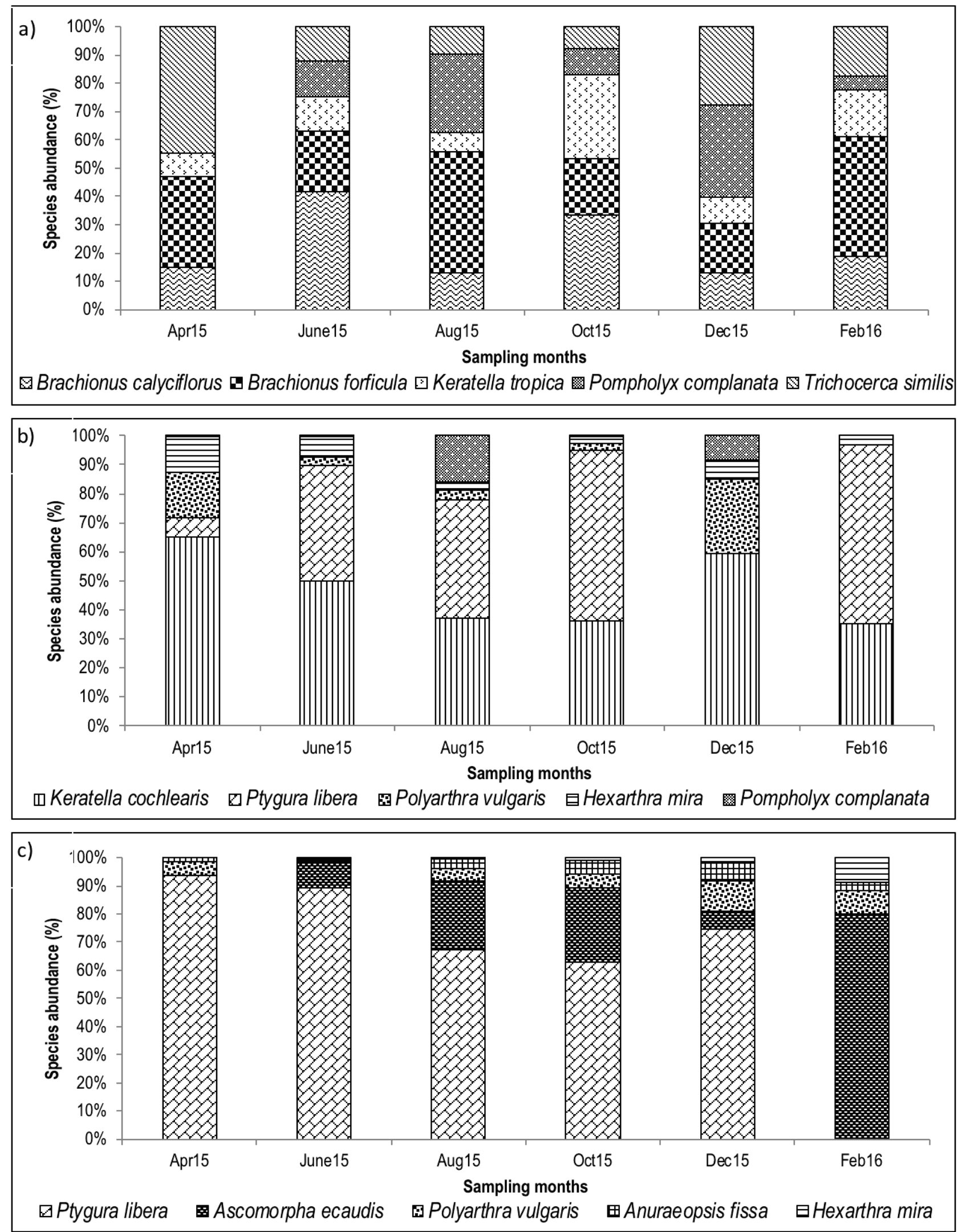

Fig. 4: Abundance of common rotifer species in (a) Sembrong, (b) Putrajaya and (c) Subang lakes 


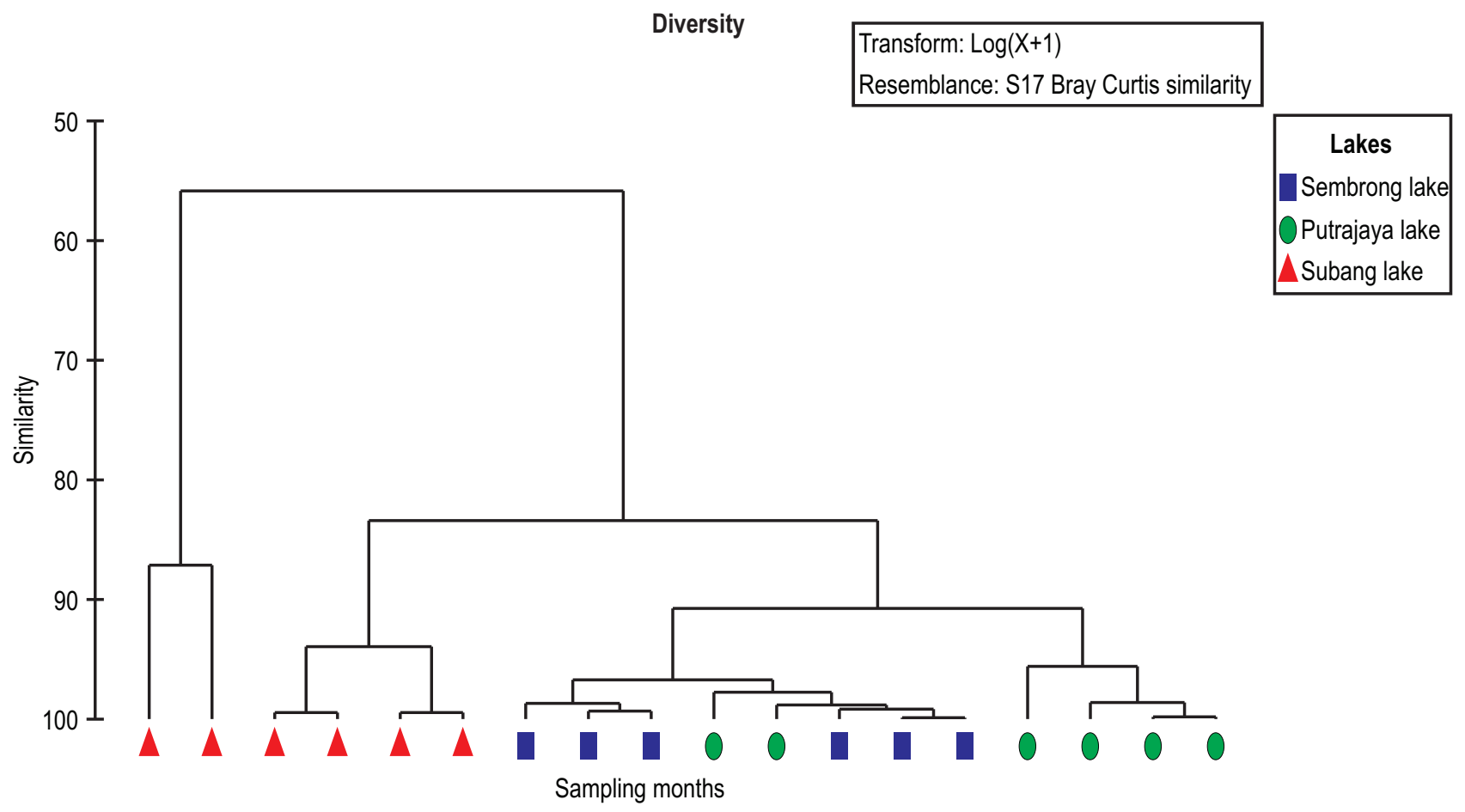

Fig. 5 : Dendrogram of rotifer diversity based on sampling months in Sembrong, Putrajaya and Subang lakes

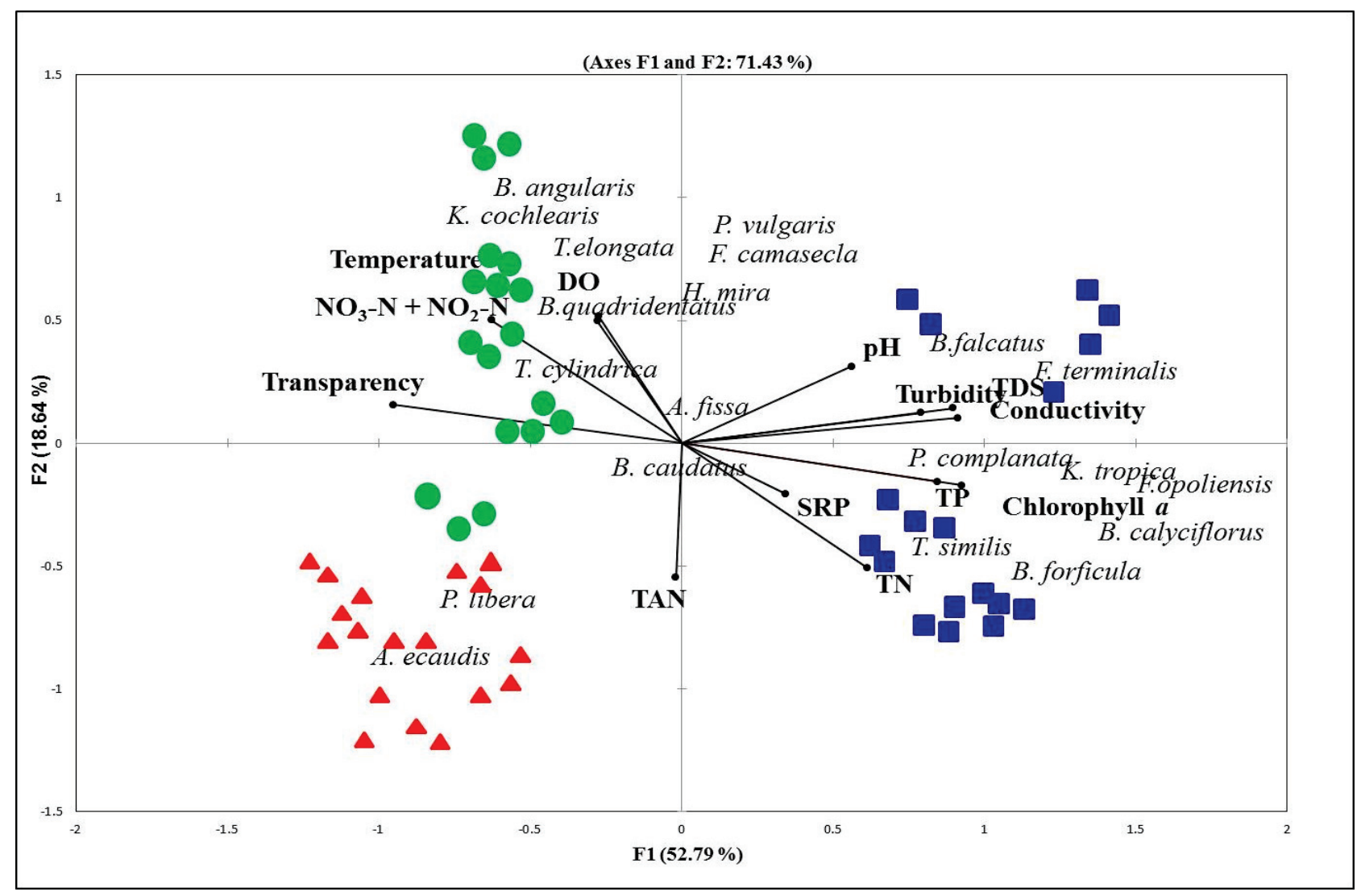

Fig. 6 : Triplot graph of canonical correspondence analysis (CCA) showing ordination of lakes, environmental parameters and distribution of rotifer species 
Table 2 : Mean species diversity and evenness of rotifers in Sembrong, Putrajaya and Subang lakes

\begin{tabular}{llll}
\hline Indices & Sembrong lake & Putrajaya lake & Subang lake \\
\hline Diversity $\left(\mathrm{H}^{\prime}\right)$ & $1.9 \pm 0.1$ & $1.5 \pm 0.1$ & $0.8 \pm 0.1$ \\
Evenness $\left(\mathrm{J}^{\prime}\right)$ & $0.7 \pm 0.0$ & $0.5 \pm 0.0$ & $0.3 \pm 0.1$ \\
\hline
\end{tabular}

Table 3 : Correlation ( $r$ ) matrices for environmental parameters and rotifers in Sembrong, Putrajaya and Subang lakes

\begin{tabular}{llllll}
\hline Parameters & Rotifer diversity & Rotifer density & Brachionus sp. & Keratellacochlearis & Ptygura libera \\
\hline Temperature & 0.05 & $0.35^{*}$ & 0.19 & $0.51^{* *}$ & 0.19 \\
DO & -0.08 & $0.28^{*}$ & 0.02 & $0.47^{* *}$ & 0.24 \\
Conductivity & $0.71^{* *}$ & $0.52^{* *}$ & $0.90^{* *}$ & $0.46^{* *}$ & $-0.45^{* *}$ \\
pH & $0.52^{* *}$ & $0.48^{* *}$ & $0.69^{* *}$ & $0.39^{* *}$ & $-0.35^{*}$ \\
TDS & $0.66^{* *}$ & $0.51^{* *}$ & $0.87^{* *}$ & $0.46^{* *}$ & $-0.47^{* *}$ \\
Turbidity & $0.67^{* *}$ & $0.50^{* *}$ & $0.83^{* *}$ & $0.44^{* *}$ & $-0.47^{* *}$ \\
Transparency & $-0.47^{* *}$ & -0.15 & $-0.62^{* *}$ & 0.08 & $0.46^{* *}$ \\
TP & $0.44^{* *}$ & 0.26 & $0.59^{* *}$ & -0.12 & $-0.49^{* *}$ \\
SRP & -0.04 & $-0.38^{* *}$ & -0.09 & $-0.38^{* *}$ & -0.27 \\
TN & $0.36^{* *}$ & 0.19 & -0.06 & -0.26 \\
$\mathrm{NO}_{3}-\mathrm{N}+\mathrm{NO}_{2}-\mathrm{N}$ & $-0.47^{* *}$ & 0.11 & $-0.49^{* *}$ & $0.32^{*}$ & $-0.41^{* *}$ \\
TAN & -0.19 & -0.21 & $-0.30^{*}$ & -0.21 & $-0.49^{* *}$ \\
Chlorophylla & $0.56^{* *}$ & -0.14 & $0.56^{* *}$ & -0.01 \\
\hline
\end{tabular}

${ }^{*}$ Significant correlation $(p<0.05),{ }^{* *}$ Significant correlation $(p<0.01)$

magnitude of the biodiversity values was sensitive both to the degree of dominance and the number of species present in each lake (McGowan and Miller, 1980). The dendrogram from the cluster analysis of rotifer diversity throughout the sampling period based on Bray Curtis similarity showed two distinct clusters at 58 $\%$ similarities (Fig. 5).

Relationship between rotifer community and environmental parameters : Rotifer species are commonly found in most types of freshwaters and their distribution is closely related to the water quality and trophic level of the water bodies. Based on the CCA ordination and plot, rotifer species showed different responses to different environmental variables (Fig. 6). The environmental variables explained $71.4 \%$ of the total variance of the species distribution. Axis 1, which accounted for a total variance of $52.8 \%$ was positively correlated with chlorophyll a, TDS, conductivity, turbidity and total phosphorus. This axis was negatively correlated with water transparency. Rotifer species such as $B$. calyciflorus, $B$. forficula and $T$. similis were all positively influenced by the Axis 1 in which their abundance was high in Sembrong lake. Keratella cochlearis, $P$. vulgaris and $B$. angularis were positively associated with slightly high temperature and dissolved oxygen in Axis 2, and were found in abundance in Putrajaya lake. However, this axis showed negative association with $P$. libera and A. ecaudis which were found to be dominant in Subang lake. These results suggested that differences in species distribution were probably due to the variation of environmental characteristics in each lake. This contention was supported by the positive correlation of $K$. cochlearis with temperature $(r=0.5, p<$
0.01 ) and dissolved oxygen $(r=0.5, p<0.01)$ (Table 3). Similarly, Veerendra et al. (2012) also found that rotifer abundance was positively correlated with temperature. High abundance of Brachionus sp. and $K$. cochlearis shared similarity in which they were highly correlated with turbidity, TDS and conductivity in both Sembrong and Putrajaya lakes (Table 3). In addition, other parameters that were associated with the high Brachionus sp. abundance in Sembrong lake was chlorophyll a $(r=0.6, p<0.01)$. This finding was similar to that of Park and Marshall (2000) who reported that high abundance of rotifers has a positive correlation with chlorophyll a concentration. Meanwhile, P. libera was inversely correlated with all parameters which influenced the abundance of rotifer species in Sembrong and Putrajaya lakes. In general, $P$. libera showed high correlation with water transparency $(r=0.5, p<0.01)$. However, high abundance of Brachionus spp. was negatively correlated with transparency $(r=$ - 0.6, p<0.01). High primary productivity, as shown by high chlorophyll a concentration, resulted in low water transparency causing light limitation for phytoplankton production in Sembrong lake.

Dominance of blue-green algae (>99\% of the total phytoplankton) in this lake was probably due to their ability to regulate their buoyancy and this mechanism provided them with the competitive advantage to overcome light limitation. Decrease of beneficial microalgal species and increase of inedible bluegreen algae could reduce the abundance of zooplankton (Imam and Balarabe, 2012). These suggest that environmental conditions should be taken into consideration for assessing rotifer 
community structure because any changes in the physical and chemical parameters influence their distribution and composition.

This study illustrated that rotifer composition and abundance were correlated with the environmental conditions of each lake. The abundance of Brachionus, Keratella and Trichocerca were related to the eutrophic condition associated with high turbidity, TDS, chlorophyll a and nutrient concentration. Ptygura libera seemed to be associated with mesotrophic waters with relatively low $\mathrm{pH}$ (4-5). This study illustrate that the dominance of rotifer species was related to the environmental conditions of the lake.

\section{Acknowledgments}

The authors wish to express their gratitude to the Ministry of Higher Education Malaysia for the financial support through the Fundamental Research Grant Scheme Project FRGS MOHE(Project number FRGS/2/2014/STWN01/UPM/01/1), SATREPS-COSMOS Matching Fund and Universiti Putra Malaysia provided Graduate Research Fellowship (GRF) to the first author. Thank you to the management of Sembrong, Putrajaya and Subang lakes for facilitating sample collections.

\section{References}

Alcaraz, M. and A. Calbet: Large zooplankton: Its role in pelagic food webs. In: Fisheries and Aquaculture. 5, 243-265. Eolss Publishers. Oxford. United Kingdom (2007).

Arndt, H.: Rotifers as predators on components of the microbial web (bacteria, heterotrophic flagellates, ciliates). A review. Hydrobiologia, 255, 231-246 (1993).

Asma', J., F.M. Yusoff, S. Banerjee and M. Shariff: Littoral and limnetic phytoplankton distribution and biodiversity in a tropical man-made lake, Malaysia. Adva. Stud. Biol., 6, 149-168 (2014).

Auel, H. and H.M. Verheye: Hypoxia tolerance in the copepod Calanoides carinatus and the effect of an intermediate oxygen minimum layer on copepod vertical distribution in the north Benguela Current upwelling system and the Angola-Benguela Front. J. Experi. Mar. Biol. Ecol., 352, 234-243 (2007).

Berge, T., N. Daugbjerg, B.B. Andersen and P.J. Hansen: Effect of lowered $\mathrm{pH}$ on marine phytoplankton growth rates. Mar. Ecol. Progr. Ser., 416, 79-91 (2010).

Bērzinš̌, B. and B. Pejler: Rotifer occurrence and trophic degree. Hydrobiologia, 182, 171-180 (1989).

Bhat, N.A., R. Rainaand and A. Wanganeo: Ecological investigation of zooplankton abundance in the Bhoj wetland, Bhopal of central India: Impact of environmental variables. Int. J. Fisher. Aquac., 7, 81-93 (2015).

Brandl, Z.: Freshwater copepods and rotifers: Predators and their prey. Hydrobiologia, 546, 475-489 (2005).

Claps, M.C., N.A. Gabellone and H.H. Benitez: Seasonal changes in the vertical distribution of rotifers in a eutrophic shallow lake whit contrasting states of clear and turbid water. Zoology Studies, 50, 454-465(2011).

Clarke, K.R. and R.M. Warwick: A further biodiversity index applicable to species lists: Variation in taxonomic distinctness. Mar. Ecol. Prog.
Ser., 216, 265-278 (2001).

Demetraki-Paleolog, A. and J. Sender: Planktonic rotifers of three eutrophic lakes of łĉczyēsko-włodawskie lakeland (Eastern Poland). Teka Komisji Ochrony i Kształtowania Środowiska Przyrodniczego, 10, 62-69 (2013).

Derry, A.M. and S.E. Arnott: Zooplankton community response to experimental acidification in boreal shield lakes with different ecological histories. Cana. J. Fisher. Aqu. Sci., 64, 887-898 (2007).

Ejsmont-Karabin, J.: The usefulness of zooplankton as lake ecosystem indicators: Rotifer trophic state index. Polish J. Ecology, 60, 339-350 (2012).

Ferdous, Z. and A.K.M. Muktadir: A Review: Potentiality of zooplankton as bioindicator. Amer. J. Appl. Sci., 6, 1815-1819 (2009).

Ferrão-Filho, A.D.S. and B. Kozlowsky-Suzuki: Cyanotoxins: Bioaccumulation and effects on aquatic animals. Marine Drugs, 9, 2729-2772 (2011).

Frutos, S.M., A.S.G. Poi de Neiff and J.J. Neiff: Zooplankton abundance and species diversity in two lakes with different trophic states (Corrientes, Argentina). Acta Limnol. Brasili., 21, 367-375 (2009).

Fulton, R.S. and H.W. Pearl: Effects of colonial morphology on zooplankton utilization of algal resources during blue-green algal (Microcystis aeruginosa) blooms. Limnol. Oceanogr., 32,634-644 (1987).

Ger, K.A., P. Urrutia-Cordero, P.C. Frost, L.A. Hansson, O. Sarnelle, A.E. Wilson and M. Lürling: The interaction between cyanobacteria and zooplankton in a more eutrophic world. Harmful Algae, 54, 128144 (2016).

Gilbert, J.J. and R.S. Stemberger: Control of Keratella populations by interference competition from Daphnia. Limnol. Oceanogr., 30, 180-188 (1985).

Gulati, R.D.: Zooplankton structure in the Loosdrecht lakes in relation to trophic status and recent restoration measures. Hydrobiologia, 191,173-188(1990).

Hsieh, C.H., Y. Sakai, S. Ban, K. Ishikawa, T. Ishikawa, S. Ichise, N. Yamamura and M. Kumagai: Eutrophication and warming effects on long-term variation of zooplankton in Lake Biwa. Biogeosciences, 8, 1383-1399 (2011).

Imam, T.S. and M.L. Balarabe: Impact of physicochemical factors on zooplankton species richness and abundance in Bompai-Jakara catchment basin, Kano State, Northern Nigeria. Bay. J. Pure Appl. Sci., 5, 34-40 (2012).

Ismail, A.H. and A.A.M. Adnan: Zooplankton composition and abundance as indicators of eutrophication in two small man-made lakes. Trop. Life Sci. Res., 27, 31-38 (2016).

Ismail, A.H. and S.A. Zaidin:A comparative study of zooplankton diversity and abundance from three different types of water body. $2^{\text {nd }}$ Inter. Conf. Agri., Environ. Biol. Sci., August 16-17, 2015 Bali (Indonesia) (2015).

Jeffries, D.S., F.P. Dieken and D.E. Jones: Performance of the autoclave digestion method for total phosphorus analysis. Water Research, 13, 275-279 (1979).

Karabin, A.: Pelagic zooplankton (Rotatoria+ Crustacea) variation in the process of lake eutrophication. 1. Structural and quantitative features. Pol. J. Ecol., 33, 567-616 (1985).

Karabin A., J. Ejsmont-Karabin and R. Korna-towska: Eutrophication processes in a shallow, macrophyte-dominated lake factors influencing zooplankton structure and density in Lake Luknajno (Poland). Hydrobiologia, 342, 401-409 (1997).

Kitamura, H., H. Ishitani, Y. Kuge and M. Nakamoto: Determination of 
nitrate in freshwater and seawater by a hydrazine reduction method. Jap. J. WaterPoll. Res., 5, 35-42 (1982).

Knops, M., R. Altenburger and H. Segner: Alterations of physiological energetics, growth and reproduction of Daphnia magna under toxicant stress. Aqua. Toxicol., 53, 79-90 (2001).

Lee, W.Y. and B.J. McAlice: Sampling variability of marine zooplankton in a tidal estuary. Estuar. Coa. Mar. Sci., 8, 565-582 (1979).

Lin, Q.Q., S.S. Duan, R. Hu and B.P. Han: Zooplankton distribution in tropical reservoirs, South China. Inter. Rev. Hydrobiol., 88, 602613 (2003).

Locke, A.: Zooplankton responses to acidification: A review of laboratory bioassays. Wat. Air Soil Poll., 60, 135-148 (1991).

Lorenzen, C.J.: Determination of chlorophyll and pheo-pigments: Spectrophotometric equations. Limnol. Oceanogr., 12, 343-346 (1967).

Maclsaac, H.J. and J.J. Gilbert: Competition between rotifers and cladocerans of different body sizes. Oecologia, 81, 295-301 (1989).

McGowan, J.A. and C.B. Miller: Larval fish and zooplankton community structure in California. Reports-California Cooperative Oceanic Fisheries Investigations (USA) (1980).

Meor Hussain, M.A.F., A. Ahyaudin, R.A. Shah and M. Shah: The structure and dynamics of net-zooplankton communities of the littoral versus limnetic zone of a typical embayment in a small flow through tropical reservoir. J. Biosci., 13, 23-34 (2002).

Mohd-Asharuddin, S., N. Zayadi, W. Rasit and N. Othman: Water quality characteristics of sembrong dam reservoir, Johor, Malaysia. In: IOP Conference Series: Materials Science and Engineering. 136(1), 012058. IOP Publishing. Langkawi, Malaysia (2016).

Mulani, S.K., M.B. Mule and S.U. Patil: Studies on water quality and zooplankton community of the Panchganga river in Kolhapur city. J. Environ. Biol., 30, 455-459 (2009).

Neves, I.F., O. Rocha, K.F. Roche and A.A. Pinto: Zooplankton community structure of two marginal lakes of the river Cuiabá (Mato Grosso, Brazil) with analysis of Rotifera and Cladocera diversity. Braz. J. Biol., 63, 329-343 (2003).

Offem, B.O., E.O. Ayotunde, G.U. Ikpi, F.B. Ada and S.N. Ochang: Plankton-based assessment of the trophic state of three tropical lakes. J. Environ. Protect., 2, 304 (2011).

Paidere, J., I.D. Deimantovica, O. Grinko, A. Brakovska and I. Brūvere: latvia during summer, 2010. Acta Biologica Universitatis Daugavpiliensis, Suppliment, 3, 65-81 (2012).

Pal, S., A.K. Patra and K. Chakraborty: Prospect of Brachionus calyciflorus, a holoplankton, for its potential bio-indicator property: Areview. Inter. J. Rec. Scie. Res. Res., 6, 7603-7608 (2015).

Perbiche-Neves, G., C. Fileto, J. Laço-Portinho, A. Troguer and M.S. Júnior: Relations among planktonic rotifers, cyclopoid copepods, and water quality in two Brazilian reservoirs. Latin American J. Aqu. Res., 41, 138-149 (2013).

Phan, D.D., V.K. Nguyen, T.N. Le, T.D. Ngoc and T.H. Ho: Identification handbook of freshwater zooplankton of the Mekong River and its Tributaries, Mekong River Commission, Vientiane., p. 207, (2015).

Panwar, S. and D.D. Malik: Zooplankton diversity, species richness and their distribution pattern in Bhimtal Lake of Kumaun Region, (Uttarakhand). Hydrol. Curr. Res., 7, 2. (2016).

Park, G.S. and H.G. Marshall: Estuarine relationships between zooplankton community structure and trophic gradients. J. Plank. Rese., 22, 121-136 (2000).
Parsons, T.R., Y. Maita and C.M. Lalli: A manual of chemical and biological methods for sea water analysis. Pergamon Press Ltd. Headington Hill Hall, Oxford OX3 OBW, England, p. 173 (1984).

Pederson, G.L., E.B. Welch and A.H. Litt: Plankton secondary productivity and biomass: Their relation to lake trophic state. Hydrobiol., 50, 129-144 (1976).

Pontin R.: A key to the freshwater planktonic and semi-planktonic rotifera of the british isles. Scientific Publication No. 38. Freshwater Biological Association, Ambleside, p. 178 (1978).

Rogozin, A.G.: Specific structural features of zooplankton in lakes differing in trophic status: Species populations. Russ. J. Ecol., 31, 405-410 (2000).

Sa-Ardrit, P., P. Pholpunthin and H. Segers: A checklist of the freshwater rotifer fauna of Thailand (Rotifera, Monogononta, Bdelloidea). J. Limnol., 72, 18(2013).

Shah, A.S.R.M., J. Ismail, D. Latief and W.M.W. Omar: The spatial structure of zooplankton communities of Pedu Reservoir, Malaysia. Wetland Sci., 10, 423-428 (2012).

Sampaio, E.V., O. Rocha, T. Matsumura-Tundisi and J.G. Tundisi: Composition and abundance of zooplankton in the limnetic zone of seven reservoirs of the Paranapanema River, Brazil. Braz. J. Biol., 62, 525-545(2002).

Sanders, R.W., K.G. Porter, S.J. Bennett and A.E. DeBiase: Seasonal pattern of bacteriovory by flagellaes, ciliates, rotifers, and cladocerans in a freshwater planktonic community. Limnol. Oceanogr., 34, 673-687 (1989).

Segers, H.: Global diversity of rotifers (Rotifera) in freshwater. Hydrobiologia, 595, 49-59. (2008).

Sharip, Z. and F.M. Yusoff: Plankton community characteristics of natural and man-made tropical lakes. J. Environ. Biol., 38, 1365-1374 (2017).

Shiel, R.J.: A guide to identification of rotifers, cladocerans and copepods from Australian inland waters (No.3). Canberra: Co-operative Research Centre for Freshwater Ecology (1995).

Sládeček, V.: Rotifers as indicators of water quality. Hydrobiologia, 100, 169-201 (1983).

Špoljar, M., T. Tomljanović and I. Lalić: Eutrophication impact on zooplankton community: A shallow lake approach. The Holi. Appr. Environ., 1,131-142 (2011).

Tasevska, O., D. Guseska and G. Kostoski: Comparison of pelagic rotifer communities in three natural Macedonian lakes. Acta Zoological Bulgaria, 4, 159-165 (2012).

Ter Braak, C.J. and P.F. Verdonschot: Canonical correspondence analysis and related multivariate methods in aquatic ecology. Aqua. Sci., 57, 255-289 (1995).

van Donk, E. and W.J. van de Bund: Impact of submerged macrophytes including charophytes on phyto- and zooplankton communities: allelopathy versus other mechanisms. Aqu. Bot., 72, 261-274 (2002).

Veerendra, D.N., S. Thirumala, H. Manjunatha and H.B. Aravinda: Zooplankton diversity and its relationship with physico-chemical parameters in Mani reservoir of Western Ghats, region, Hosanagar Taluk, Shivamoga district Karnataka, india. J. Urb. Environ. Engg., 6, 74-77 (2012).

Wang, C., L. Wang, D. Deng and Z. Zhou: Temporal and spatial variations in rotifer correlations with environmental factors in Shengjin Lake, China. Environ. Sci. Poll. Rese., 23, 8076-8084 (2016).

Yoshida, T., J. Urabe and J. Elser: Assessment of "top-down" and "bottom-up" forces as determinants of rotifer distribution among lakes in Ontario, Canada. Ecol. Res., 18, 639-665(2003). 